SLOVO, sv. 68 (2018), 289-308, Zagreb 2018.

Jerzy OSTAPCZUK

UDK $27-247=163.1$

Wydział Teologiczny

091(495.631)

Chrześcijańska Akademia Teologiczna w Warszawie

Izvorni znanstveni članak

jostap@wp.pl

Primljen: 2. veljače 2018.

Prihvaćen: 11. rujna 2018.

\title{
ЛИТУРГИЧЕСКИЕ ОСОБЕННОСТИ В СТРУКТУРЕ РУКОПИСНЫХ ЕВАНГЕЛИЙ СОБОРНО-ПРИХОДСКОГО БОГОСЛУЖЕНИЯ ИЗ АФОНСКИХ МОНАСТЫРСКИХ ХРАНИЛИЩ
}

Статья содержит общие сведения о церковнославянских рукописных Евангелиях хранящихся на св. горе Афон и описание литургических особенностей первых двух периодов синаксарной части богослужебного календаря (Пасхального и после праздника Пятидесятницы) в двух кратких апракосах. Первая рукопись хранится в монастыре св. Пантелеймона (№ 4), а вторая в Зографском монастыре (№ 16) на св. горе Афон. В статье обсуждается возможность использования этих двух евангельских кратких апракосов, предназначенных для соборно-приходского богослужения, в монастырском ежедневном богослужении.

Ключевые слова: литургические особенности, краткий апракос, св. гора Афон

\section{1. СЛАВЯНСКИЕ РУКОПИСНЫЕ ЕВАНГЕЛИЯ В АФОНСКИХ МОНАСТЫРЯХ}

В афонских монастырях на сегодняшний день хранится немало славянских рукописей. Среди них находятся и книги с евангельским текстом. Предварительный подсчет, проведенный на основе опубликованных каталогов и научных изданий, показал, что в Греции хранится достаточно много рукописных Евангелий, ${ }^{1}$ из которых подавляющее большинство

1 Количество рукописных Евангелий может поменяться в случае: (1) обнаружения новых рукописей и введения их в научный оборот или (2) отождествления фрагментов с основной частью рукописи. Примером первого является описание единицы № 94 из собрания Пантелеймонова монастыря как »Картонаж« и публикация фотографии (ČEŽIÂ 2013: 68) на которой можно прочесть фрагменты из Евангелия от Иоанна (левая половина 
находится на Афоне. ${ }^{2}$ В эти выкладки не включены литургические рукописи (т. е. Служебники, Требники ${ }^{3}$ и т. п.), в которых объем евангельского (очень часто и апостольского) текста довольно небольшой (иногда всего несколько чтений), ${ }^{4}$ и потому он не является их главным ядром. В настоящее время на Афоне хранится $148^{5}$ рукописей и фрагментов Евангелия. Учитывая их типологическую классификацию, статистика складывается следующим образом:

- тетраевангелия - 130 рукописей; ${ }^{6}$

- полные апракосы - 6 рукописей (Хиландарский монастырь № 8, 9, 14,31 , Зографский монастырь № 22 и 23 );

- краткие апракосы - 3 рукописи (Пантелеймонов монастырь № 4, Зографский монастырь № 16 и № $283^{7}$ (два листа));

- сверхкраткие апракосы - 2 рукописи, т. е. один субботне-воскресный апракос (Хиландарский монастырь № 63) и один столпный (Пантелеймонов монастырь № 8).

7,16-17 (верх) и 7,21-23 (низ), правая половина 7,32-36 и указание (с угла листа) на евангелиста (ıш )). Эти фрагменты из Евангелия в такой последовательности происходят из тетра. Подробнее об этом фрагменте см. OSTAPČUK 2015: 306-308. Примером второго случая является идентификация одного листа из собрания Пантелеймонова монастыря № 78 как части рукописи Евангелия дьяка Бунила из Хиландарского монастыря № 23 (TURILOV 2006: 56-57, 66-68, 81-82; TURILOV 2010: 348-352; ČEŽIÂ 2013: 61).

2 За пределами Афона хранятся только две кириллические рукописи с евангельским текстом: в Национальной Библиотеке в Афинах № 1796 (STANČEV; DŽUROVA 1981: 2) и в монастыре Пруссос № 72 (Svodnij katalog XIV v.: прил. I.348).

3 Ср. фрагмент (3 листа) рукописного Требника из собрания Пантелеймонова монастыря № 86, в котором находится чтение »пророком« (TURILOV; MOŠKOVA 1999: 395-396 (№ 988); ČEŽIÂA 2013: 65 (№ 86)) или рукопись Служебника из собрания Пантелеймонова монастыря № 258, на иллюстрации фрагмента которого выписано чтение из Апостола (С̆EŽIÂA 2013: 156 (№ 258)).

4 Греческие литургические рукописи (т. е. между прочим требники, служебники, и другие) с несколькими евангельскими чтениями обозначаются сокращением $l$ Lit (ALAND 1963: 24).

5 Всего на Афоне хранится 150 единиц евангельских рукописей и фрагментов. При этом один лист из Пантелеймонова монастыря № 78 и рукопись № 23 Хиландарского монастыря составляют одну рукопись (С̌EŽIẦ 2013: 61 (№ 78)); три листа из Пантелеймонова монастыря № 77 и рукопись № 3-47 Великой лавры также составляют одну рукопись (TURILOV; MOŠKOVA 1999: 68 (№ 128 и № 133)).

6 В типологической классификации 2 листов из Хиландарского монастыря № 43a есть сомнения (см. TURILOV; MOŠKOVA 1999: 63 (№ 115)).

7 Два листа из собрания Зографского монастыря № 283 являются частями Рильского Евангелия Б (Рильский Монастырь № 1/12) и Евангелия (краткого апракоса) из Национальной Государственной Библиотеки в Бухаресте № 10848 (MUSAKOVA 2009: 477-494; OSTAPČUK 2015: 310-311). 
Из-за плохой сохранности рукописных Евангельских фрагментов и недостаточной информации об опубликованных отрывках четкая типологическая классификация 8 единиц хранения оказалась невозможной. ${ }^{8}$

Преобладающее большинство (2/3) четвероевангелий в собраниях Афона ${ }^{9}$ - это рукописи, датируемые XV, XVI и XVII веками. Остальные 38 тетраевангелий относятся к XIV веку и 9 к XIII веку. Шесть полныХ афонских апракосов датируются XIV и один XIII веком. Такая картина становится более понятной, если учитывать три следующих факта: а) значительное число афонских рукописей (в том числе и древнейших) хранится сегодня за пределами Афона; б) с сер. XIV - нач. XV века ${ }^{10}$ четвероевангелия вытесняли из употребления апракосы; ${ }^{11}$ в) в южнославянской традиции были популярны тетраевангелия, связанные с литургической реформой св. Саввы Сербского. ${ }^{12}$

\section{2. ТИПОЛОГИЧЕСКАЯ КЛАССИФИКАЦИЯ ЕВАНГЕЛИЙ И МОНАСТЫРСКАЯ БОГОСЛУЖЕБНАЯ ПРАКТИКА}

Из приведенных данных видно, что на территории, где находятся исключительно монастыри, в которых литургия должна совершатся ежедневно (за исключением будничных дней - понедельника-пятницы - Beликого Поста и еще нескольких дней в году), преобладают рукописи, с помощью которых обеспечивается литургическая повседневная жизнь ее насельников, т. е. монахов. Такая картина является вполне логичной. Только полные апракосы и литургические четвероевангелия, т. е. тетры с

\footnotetext{
${ }^{8}$ Хиландар № 68a, 73a, 486a и 760III; Зографский монастырь № 21, 211, 282 и 291. Все указанные фрагменты, кроме двух последних, с большой вероятностью могли быть частью апракосов.

${ }^{9}$ Кроме указанных Евангелий, в афонских хранилищах находятся и другие - младшие рукописи. На примере собрания Пантелеймонова монастыря можно указать на: »Евангелие для домашнего чтения« (№ 212, сер. - трет. четв. XIX в., 93 л.), которое »состоит из подборок Евангельских чтений (иногда соответствующих зачалам) с сентября по август« (С̌EŽIÂ 2013: 133); Новый Завет на русском языке (№ 213, 1859 года, 239 л.) (ČEŽIÂ 2013: 134); 12 Страстных Евангелий (№ 229, кон. XIX в., 86 л.) (ČEŽIÂ 2013: 142); »Устав о чтении Евангелия« в Руссиконе (№ 539, 1878 года, 2 л.) (ČEŽ̌ÂA 2013: 302). Исследование этих поздних рукописей, датируемых XIX столетием, может дать интересные результаты.

${ }^{10}$ IOANN 1998: 18 (І. пагинации).

${ }^{11}$ В греческой традиции апракосы вытеснили четвероевангелия (IOANN 1998: 13 (III. пагинации)).

12 OSTAPCZUK 2010.a: 109-110.
} 
полной ${ }^{13}$ литургической разметкой, соответствующие полным апракосам, обеспечивают требования монастырской жизни православных монастырей. Использование в монастырской жизни других видов Евангелия, т. е. кратких и сверхкратких апракосов, для совершения ежедневных евхаристических богослужений в полном годовом кругу невозможно. Эти виды апракосов не содержат евангельских чтений на все дни подвижного календарного года. В кратких апракосах (lesk), ${ }^{14}$ соответствующих соборно-приходской литургической практике, ${ }^{15}$ в сравнении с полными отсутствуют чтения на понедельник-пятницу в период после праздника Пятидесятницы и Нового Лета. Эти периоды имеют обычно зачала на 16 или 17 недель. Из этого видно, что в кратких апракосах недостает 160 или 170 богослужебных литургических зачал. В сверхкратких апракосах, к которым принадлежат апракосы субботне-воскресный (lsk), воскресный $(l \mathrm{k})$ и пасхально-воскресный $(l \mathrm{ek})$, отсутствует еще более значительное количество евангельских чтений. Принцип использования в богослужении так называемого столпного апракоса, один рукописный экземпляр которого хранится в Пантелеймоновом монастыре (№ 8), совсем другой. ${ }^{16}$

Тем не менее в монастырях на св. горе Афон хранятся церковнославянские евангельские рукописи, с помощью которых невозможно обеспечить требования монастырского устава, по которому литургия должна совершатся ежедневно. Количество этих рукописей невелико. На 136 афонских четвероевангелий и полных апракосов приходится только один субботне-воскресный апракос (Хиландарский монастырь № $63\left(l^{+a} \mathrm{sk}\right.$; ок. 1425 г.)) и два кратких: ${ }^{17}$

- Апостол-апракос краткий и Евангелие-апракос краткое из собрания Свято-Пантелеймонова монастыря, рукопись № 4 (далее - Пн-4)

${ }^{13} \mathrm{~B}$ славянской рукописной традиции известны рукописные четвероевангелия, содержащие частичную или полную литургическую разметку (указания) (VRANA 1960: 552-553; MOSZYŃSKI 1985: 76-99). Подробнее см. OSTAPCZUK 2010.a: 92-122.

14 Сокращение lesk соответствует церковнославянским кратким апракосам.

15 TEMČIN 2010.b: 147.

16 Этот вид апракоса, содержащий не ряд евангельских чтений, а несколько столпов (апостольских и) евангельских чтений, обычно указывается как четвертый (TEMČIN 2010.b: 148)). Подробнее об этом виде апракоса и принципе его использования в богослужениях см. OSTAPCZUK 2010.a: 85-91 (и цитируемая литература).

17 Два листа из Зографского монастыря, хранящиеся под № 283, представляют собой фрагмент краткого апракоса, главная часть которого находится в Национальной Государственной Библиотеке в Бухаресте № 10848 (MUSAKOVA 2009: 477-494; OSTAPČUK 2015: 310-311; ср. сноска 8). 
- Евангелие-апракос краткое из собрания Зографского монастыря, рукопись № 16 (далее - Зг-16).

Обе рукописи давно введены в научный оборот.

\section{3. АПОСТОЛ-АПРАКОС КРАТКИЙ И ЕВАНГЕЛИЕ-АПРАКОС КРАТКОЕ ИЗ СВЯТО-ПАНТЕЛЕЙМОНОВА МОНАСТЫРЯ № 4 (Пн-4)}

Первый апракос Пн-4 ученые упоминали в каталогах и палеографических альбомах славянских рукописей и в научных работах ${ }^{18}$ (М. А. Бобрик; М. Гарзанити; монах Ермолай (Чежия); Й. Иванов; Н. Ф. Ковязина; П. А. Лавров, О. В. Лосева; В. Ф. Мареш; В. Мошин; Ш. Пилат; Љ. Стојановић; А. Е. Тахиаос; А. А. Турилов, он же совместно с Л. В. Мошковой; Б. Христова, Д. Караджова, Е. Узунова), ${ }^{19}$ а также в предварительных

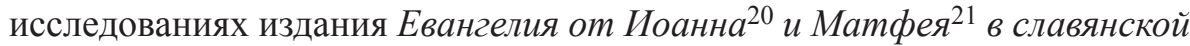
традиичи. Ш. Пилатом, защитившим диссертацию в 2014 г., ${ }^{22}$ готовится научное издание памятника, ${ }^{23}$ к сожалению, только Апостола.

Рукопись Пн-4, состоящая из 202 листов, содержит две части. Апостол ( $\left.l^{\mathrm{a} e s k: ~ л . ~} 1-77 v\right)$ ученые обычно датируют 1313 годом, а Евангелие (lesk: л. 78-201v) кон. XIII - нач. XIV века. ${ }^{24}$ По последней датировке второй части рукописи, проведенной А. А. Туриловым, Евангелие считается современным Апостолу и датируется ок. 1313 г. ${ }^{25}$ Апостол пере-

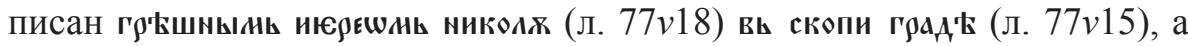

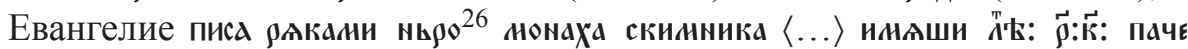
и вАџє (л. 201v25-27). 202 лист, находящийся после последнего коло-

18 Рукопись этого краткого апракоса была использована в работах автора настоящей статьи. См. отдельные статьи OSTAPCZUK 2008: 21-53; 2009: 70-78; 2013: 197-213.

19 BOBRIK 2014: 235-237; 2015: 69-88; GARZANITI 2001: 525; ČEŽIÂ 2013: 20 (№ 4); IVANOV 1931: 104-105; KOVÂZINA 2000: 58; LAVROV 1916: 138; LOSEVA 2001: 100; MAREŠ 1985: 119-122; MAREŠ 1984-1985: 37-47; MOŠIN 1966: 59; PILAT 2013: 165 181; STOJ̌ANOVIĆ 1902: 19 (№ 43); TACHIAOS 1981: № 4; TURILOV 2012: 120-126; TURILOV, MOŠKOVA 1999: 43-44 (№ 54); HRISTOVA; KARADŽOVA; UZUNOVA 2003: 38. 98. 154; № 413.

20 IOANN 1998: 75 (III. пагинации).

${ }^{21}$ MATFEJ 2005: 167.

22 PILÁT 2014.

23 TURILOV 2012: 120.

${ }^{24}$ TURILOV; MOŠKOVA 1999: 43-44 (№ 54); ČEŽIÂ 2013: 20 (№ 4).

25 TURILOV 2012: 124.

${ }^{26}$ А. А. Турилов предложил именовать писца Нероном (TURILOV 2012: 124). 
фона и содержащий указания чтений дневных Апостолов и Евангелий, писан третьим писцом. Так как Евангелие создавалось одновременно ${ }^{27}$ с Апостолом, предполагается, что оно переписано где-то в болгарском скриптории северной Македонии. ${ }^{28}$ Славянский перевод Евангелия ${ }^{29}$ в этом апракосе считается самым древним. ${ }^{30}$

\section{4. ЕВАНГЕЛИЕ-АПРАКОС КРАТКОЕ ИЗ СОБРАНИЯ ЗОГРАФСКОГО МОНАСТЫРЯ № 16 (ЗГ-16)}

Второй краткий апракос из афонских хранилищ Зг-16 известен в науке более ста лет. ${ }^{31}$ Но такого внимания ученых как первый, он не привлекал. Евангелие учитывалось в каталогах славянских рукописей и в научных работах Г. А. Ильинского, Х. Кодова, Б. Райкова, С. Кожухарова и Х. Микласа, А. А. Турилова и Л. В. Мошковой, М. Гарзанити. ${ }^{32}$ Писанный полууставом на 175 бумажных листах (28х20 цм.) апракос Зг-16 содержит только Евангелие (lesk). Эта среднеболгарская рукопись датируется кон. XV - нач. XVI века. ${ }^{33}$ В каталоге Славянских рукописей Афонских обителей местом создания апракоса с вопросительным знаком указана Украина или Беларусь. ${ }^{34}$

\section{5. ХАРАКТЕРИСТИКА КРАТКИХ АПРАКОСОВ}

Наличие в монастырских собраниях св. Афонской горы двух рукописных евангельских кратких апракосов, соответствующих соборноприходской богослужебной практике, а не монашеской, поднимает несколько вопросов. Среди них ${ }^{35}$ можно указать на способ использования

27 TURILOV 2012: 124.

${ }^{28}$ TURILOV 2012: 125.

29 Об отдельных частях евангельского апракоса в этой рукописи см. OSTAPCZUK 2010.а: 25; См. OSTAPCZUK 2013: 197-214.

${ }^{30}$ MATFEJ 2005: 167.

31 IL'INSKIJ 1908: 258 (№ 18).

${ }^{32}$ IL'INSKIJ 1908: 258 (№ 18); KODOV; RAJKOV; KOŽUHAROV 1985: 73-74 (№ 34); RAJKOV; KOŽUHAROV; MIKLAS; KODOV 1994: 36 (№ 16); TURILOV; MOŠKOVA 1999: 58 (№ 101); GARZANITI 2001: 525.

33 TURILOV; MOŠKOVA 1999: 58 (№ 101). Г. А. Ильинский датировал рукопись XV в. (IL'INSKIJ 1908: 258 (№ 18)).

34 TURILOV; MOŠKOVA 1999: 58 (№ 101).

35 Присутствие в монастырях кратких апракосов, не соответствующих монашеской богослужебной (ежедневной) практике, ставит вопрос об их происхождении: каким образом они туда попали, были там переписаны, подарены, пожертвованы или заказаны. 
этого вида апракосных евангелий в ежедневных богослужениях, кем и как они использовались в монастырских службах, было ли это вообще возможно.

Во всех апракосах, кроме столпных, выделяется несколько частей. Первая, начинающаяся чтением на литургию Светлого Воскресенья Христова, соответствует подвижному календарному кругу, в котором выделяется пять периодов: Пасхальный, после праздника Пятидесятницы, Нового Лета, Великого Поста и Страстной Недели. Вторая часть апракосов, начинающаяся с 1 сентября, соответствует неподвижному календарному кругу, разделяющемуся на 12 месяцев. В третьей части апракосов находятся 12 утренних воскресных Евангелий и чтения на »всякую потребу«.

Типологическая классификация апракосов основана на количестве евангельских зачал в их первой части. В кратких апракосах, согласно применяемому к греческим ${ }^{36}$ рукописям сокращению lesk, в пасхальный

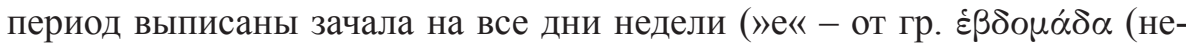
деля)), а во все следующие периоды (кроме Страстной Недели) - только

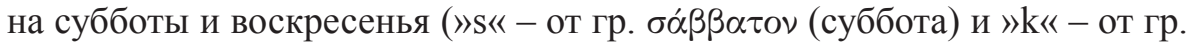
Kvрıххй (воскресенье)). Это теоретическое основание, в практике которого имеют место исключения.

\section{6. ЛИТУРГИЧЕСКИЕ ОСОБЕННОСТИ АФОНСКИХ КРАТКИХ АПРАКОСОВ}

\section{1. Пасхальный период}

Оба кратких апракоса (Пн-4 и Зг-16) в пасхальный период содержат евангельские чтения на все дни недели, с воскресенья по субботу, включая Праздник Пятидесятницы. Но некоторые из зачал в Пн-4, как и в других апракосах как и в тексте этой же рукописи, находящемся после пасхального периода, имеют форму отсылок к другим местам в памятнике, где евангельские чтения выписаны полностью. Это касается зачал ${ }^{37}$ субботы 3 недели, пятницы и субботы 6 недели и первых шести дней 7 недели (с воскресенья по пятницу). ${ }^{38}$ В младшем апракосе Зг-16 все

\footnotetext{
${ }^{36}$ ALAND 1963: 24.

${ }^{37}$ В этом периоде отсылки имеют и другие евангельские зачала, т.е. вторник 1 недели; воскресенье 2 недели; воскресенье и суббота 3 недели; четверг, пятница и суббота 6 недели; воскресенье, понедельник, вторник, среда, четверг, пятница и суббота 7 недели. См. OSTAPCZUK 2010.a: 256-261.

38 О некоторых особенностях отсылок в Пн-4 см. OSTAPCZUK 2008: 34-37.
} 
зачала пасхального периода выписаны полностью. Присутствие отсылок в апракосах является их архаической чертой ${ }^{39}$ и указывает на сохранившуюся в них древнюю традицию.

\section{2. Период после Праздника Пятидесятници}

В период после праздника Пятидесятницы все зачала в Пн-4 и Зг-16 выписаны полностью. Отсылки для евангельских чтений в этот период встречаются иногда в других рукописных кратких апракосах. ${ }^{40}$ Они касаются преимущественно ${ }^{41}$ чтения субботы 17 недели, отсутствующие в Пн-4 вместе с зачалом на воскресенье этой недели. ${ }^{42}$ Наличие в апракосах чтений только на 16 недель после праздника Пятидесятницы, что имеет место в Пн- 4 , является архаической чертой ${ }^{43}$ и указывает на древнюю, неразвитую еще до конца богослужебную традицию евангельских чтений.

Начиная со дня св. Духа, т. е. понедельника после праздника Пятидесятницы, по Лазареву субботу (в течение трех периодов - после праздника Пятидесятницы, Нового Лета и Великого Поста), все краткие апракосы должны иметь чтения только на субботы и воскресенья. Это обстоятельство имеет место только в первой рукописи - Пн-4. В Зг-16 картина выглядит по-другому. В этом апракосе евангельские зачала чтений с понедельника по пятницу полностью выписаны для двух недель: первой недели периода после праздника Пятидесятницы и первой недели периода Нового Лета. Не учитывая чтения понедельника (т. е. на Духов День), которое должно содержатся во всех кратких апракосах, зачала Евангелия от Матфея в Зг-16 (л. 41v1-43r8) выписаны следующим образом:

- вторник - Мф 4,25-5,13;44

- среда - Мф 5,20-26;

\footnotetext{
39 TEMČIN 2010.a: 93.

${ }^{40}$ См. OSTAPCZUK 2013: 317-329, 365-373.

${ }^{41}$ В этом периоде отсылки имеют зачала субботы 5 и 10 недели, воскресенья 13 и 16 недели. См. OSTAPCZUK 2013: 320, 323-324, 326, 328-329.

$42 \mathrm{O}$ субботнем и воскресном чтении 17 недели в кратких апракосах см. OSTAPCZUK 2013: 365-373.

${ }^{43}$ См. OSTAPCZUK 2013: 378-380.

44 Разница между этими зачалами в кратких апракосах касается только вторника. Они могут выглядеть следующим образом: Мф 4,25-5,13, Мф 4,23-5,12 или Мф 4,23-5,13. См. OSTAPCZUK 2013: 354-357.
} 
- четверг - Мф 5,27-32;

- пятница - Мф 5,33-41.

Не только в греческой, ${ }^{45}$ но и в церковнославянской традиции известны рукописи кратких апракосов, в которых содержатся чтения на понедельник-пятницу первой недели после праздника Пятидесятницы. Как пример можно указать на три рукописи: № 107 из Румянцевского собрания Российской государственной библиотеки в Москве (далее Рм-107), № 1 из собрания Кирилло-Белозерского Монастыря Российской Национальной Библиотеки в Санкт-Петербурге (далее КБ-1) и № 6 из Румынской Академии Наук в Бухаресте (далее АР-6). Считается, что краткие апракосы, содержащие чтения на понедельник-пятницу после праздника Пятидесятницы, были переписаны из полных апракосов. ${ }^{46}$ На это указывает присутствие в Мф 5,22 интерполяции рака во нарєчєт $\mathfrak{c A s}^{47} \mathbf{c y \rho b -}$ ски оПльвань, характерной для рукописей, входящих в текстологическую семью полного апракоса Мстиславова Евангелия. В рукописных и старопечатных четвероевангелиях эта интерполяция не найдена. ${ }^{48} \mathrm{~B}$ этих трех славянских рукописях (Рм-107, КБ-1 и АР-6) содержатся чтения на вторник-пятницу после праздника Пятидесятницы, что подтверждается и типом этих зачал, ${ }^{49}$ являющихся полноапракосными по происхождению. В рукописи Зг-16 картина выглядит немного иначе. В этом кратком апракосе, содержащем чтения на вторник-пятницу после праздника Пятидесятницы, в Мф 5,22 этой полноапракосной интерполяции нет. Этот факт указывает на происхождение этих зачал из четвероевангелия. На использование тетра во время составления этого апракоса (или его протографа) указывают (на примере периода после праздника Пятиде-

${ }^{45}$ См. OSTAPCZUK 2010.a: 31 (сноска № 73); OSTAPCZUK 2013: 347-348.

46 TEMČIN 1998: 158-160; OSTAPCZUK 2016: 120.

${ }^{47}$ В рукописи № 1 из собрания Кирилло-Белозерского монастыря Российской Национальной Библиотеки в Санкт-Петербурге написано ९ӗ́⿴囗十 $\mathfrak{c}$.

48 TEMČIN 1998: 145, 158.

49 Сравни форму чтений (OSTAPCZUK 2013: 351):

Мстиславский тип:

Понедельник: $\quad$ Мф 18,10-20

Вторник: М $\quad$ М 4,23-5,13

Среда: $\quad$ Мф 5,20-26

Четверг: $\quad$ Мф 5,27-32

Пятница: Мф 5,33-41
Мирославский тип:

Мф 18,10-20

Мф 4,25-5,12

Мф 5,20-30

Мф 5,31-41

Мф 7,9-18

Подробнее о Мстиславском и Мирославском типе см.: ŽUKOVSKAÂ 1968: 252-260; ŽUKOVSKAÂ 1971: 86-87; ŽUKOVSKAÂ 1976: 6.284-290; IOANN 1998: 45 (III пагинации). 
сятницы) некоторые евангельские чтения, в начале которых (суббота 10 и 15 недели) или в их конце (суббота 16 недели) находятся пропущенные обычно в апракосах части начальных или завершающих стихов, или лишняя в апракосах информация типа начало-конец с указанием на день (например: $\boldsymbol{\kappa} \boldsymbol{\omega}^{\overrightarrow{4}} \mathfrak{c} \boldsymbol{x}^{\overrightarrow{5}}$ (суббота 16 недели)). ${ }^{50}$

Такая картина может быть отражением греческой традиции ${ }^{51}$ или особым отношением к этой неделе, будничные дни которой, с литургической точки зрения, принадлежали Пасхальному периоду и считались как попразднство праздника Пятидесятницы. ${ }^{52}$ Следует подчеркнуть, что продолжение празднования Пятидесятницы и дня Святого Духа, имеющее свою праздничную октаву $y^{53}$ (лат. octo), до пятницы характерно для монастырской традиции ${ }^{54}$. Иным основанием такой картины могла быть смена литургических книг, совпадающая почти со сменой евангелистов и с границей периодов Пасхального и после праздника Пятидесятницы. Триодь цветная использовалась с Лазаревой субботы по Неделю Всех святых (т. е. первую неделю после праздника Пятидесятницы), а Октоих - со следующего по ней понедельника. С использованием этих книг совпадал принцип евангельских чтений: во все дни недели - в Пасхальный период, а в субботу и воскресенье - все следующие периоды.

\section{3. Первая неделя Нового Лета в Зг-16}

В апракосе Зг-16 зачала на понедельник-пятницу выписаны не только для первой недели после праздника Пятидесятницы, но и для первой недели Нового Лета (62r21-65r3):

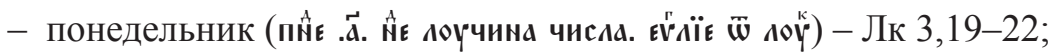

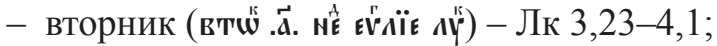

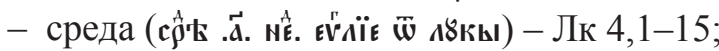

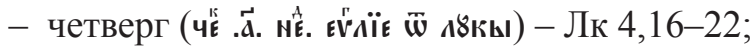

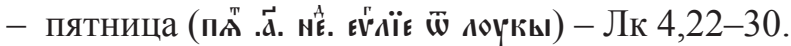

Поскольку присутствие чтений на понедельник-пятницу из Евангелия от Матфея первой Пентикостной недели является легко объяснимым

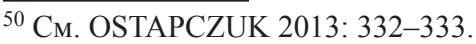

${ }^{51}$ OSTAPCZUK 2010.a: 63.

52 ŠMEMAN 1961: 102; ANCHIMIUK 1980: 87 (сноска № 1); KERN 1999: 107; IOANN 1998: 23 (III. пагинации).

${ }^{53}$ BOBRINSKOY 2004: 125.

${ }^{54}$ IOANN 1998: 23 (III. пагинации).
} 
и вполне понятным с литургической точки зрения, то присутствие зачал из Евангелия от Луки на понедельник-пятницу первой недели Нового Лета можно объяснить только как столп дневных евангельских чтений, 55 соотносящихся с подвижным годовым кругом и соответствующих рядовым $^{56}$ Евангелиям на понедельник-пятницу, находящимся в полных апракосах. ${ }^{57}$ Этот столп дневных евангельских зачал, аналогично к столпу евангельских чтений по гласам Октоиха, мог употреблятся с понедельника второй недели после праздника Пятидесятницы (т. е. понедельника по воскресении Всех Святых) до Великого Поста (во время которого Евангелие на литургиях читается только по субботам и воскресеньям). Ведь в Зг-16 чтения для всех дней недели выписаны только с Лазаревой Субботы по воскресение Всех Святых. Присутствие в кратком апракосе Зг-16 небольшого столпа дневных евангельских чтений, повторяющегося каждую неделю, давало возможность использования этой книги как полноапракосного ${ }^{58}$ Евангелия в периодах после праздника Пятидесятницы и Нового лета. ${ }^{59}$ Такой краткий апракос - со столпом дневных чтений по гласам Октоиха - соответствовал требованиям монастырской жизни и мог ежедневно употребляться в небольших храмах, общинах и монастыpях или скитах, лишенных полного комплекта богослужебных книг. ${ }^{60}$

Такой выбор столпа дневных евангельских чтений из зачал периода Нового лета как в Зг-16 вполне возможен. Евангельские и апостольские столпы (что подтверждают чтения по гласам Октоиха) выбирались из зачал периода после праздника Пятидесятници, ${ }^{61}$ Нового лета ${ }^{62}$ или даже

55 Дни недели посвящаются памяти определенных святых или библейской истории (т. е. понедельник - бесплотным силам (ангелам), вторник - Иоанну Предтече, среда - Богородице, четверг - апостолам и св. Николаю, пятница - Кресту, суббота - всем святым и усопшим) и совпадают с общими евангельскими чтениями. Общие евангельские чтения и дневные зачала - это один и тотже самый столп, который может использоваться и в неподвижном годовом круге (ТEMČIN 1999: 187).

56 Так как в функции дневного субботнего или воскресного чтения могли использоваться любые субботние или воскресные зачала подвижного годового круга (TEMČIN 1999: 186, 193).

57 TEMČIN 1999: 173, 187.

${ }^{58}$ С. Ю. Темчин отметил, что »Дневные евангельские чтения могли дополнять краткий апракос и/или заменять собою полный апракос точно так же, как общая минея могла дополнять Минею праздничную и/или заменять собою полный годовой комплект служебных миней« (TEMČIN 1999: 174).

59 TEMČIN 1999: 174.

${ }^{60}$ TEMČIN 1999: 174.

${ }^{61}$ TEMČIN 2001: 155.

${ }^{62}$ OSTAPCZUK 2010.b: 63-64. 
Пасхального. ${ }^{63}$ Любое рядовое субботнее зачало из первой части апракоса (т.е. соответствующее подвижному календарному кругу) могло использоваться как столпное субботнее евангельское чтение. ${ }^{64}$ Такой факт подтвержден в субботне-воскресном апракосе из Церковно-Археологического Музея в Софии (№ 38, пол. XV в., 347 л.), где субботнее столп-

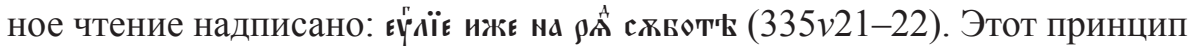
может касаться и других дней недели. ${ }^{65}$

\section{7. ЗАКЛЮЧЕНИЕ}

Исследование, проведенное на основе данных первых двух богослужебных периодов (Пасхального и после праздника Пятидесятницы) на примере двух афонских кратких апракосов, показало их большое значение для научных исследований в области палеославистики, текстологии ${ }^{66}$ или истории литургики.

Присутствие отсылок для евангельских зачал и отсутствие евангельских чтений на субботу и воскресение 17 -ой недели в рукописи Пн-4 подтверждают факт, что в этом памятнике нашла отражение древняя, ${ }^{67}$ еще не вполне развитая богослужебная традиция евангельских чтений.

Присутствие в рукописи Зг-16 указаний на начало или конец евангельских богослужебных зачал и отсутствие в Мф 5,22 характерной для полных апракосов интерполяции показали, что при составлении этого краткого апракоса было использовано именно четвероевангелие, а не полный апракос. Тем самым присутствующие в памятнике Зг-16 евангельские чтения будничных дней первых недель после праздника Пятидесятницы и Нового лета, как и все другие евангельские зачала, имеют не полноапракосное (как в случае трех вышеуказанных кратких апракосов Рм-107, КБ-1 и АР-6), а четвероевангельское происхождение.

Присутствие столпа дневных чтений только в одном из всех известных кратких апракосов - в Зг-16 - указывает на возможность употребления этого типа евангельской книги, предназначенной для соборно-приходской богослужебной жизни, в ежедневном монастырском богослужении.

\footnotetext{
63 TEMČIN 2010.b: 178. 188-189; OSTAPCZUK 2010.b: 60 (сноска № 37).

64 TEMČIN 1999: 183.

${ }^{65}$ С. Ю. Темчин указал и на воскресенье (TEMČIN 1999: 186).

${ }^{66}$ Cм. OSTAPCZUK 2008: 21-53; OSTAPCZUK 2013: 197-213.

${ }^{67}$ По словам А. А. Турилова, графико-палеографические данные этого памятника могут употребляться в характеристике ситуации в болгарских скрипториях северной Македонии на рубеже XII-XIII веков (TURILOV 2012: 124-125).
} 
Недостающее немалое количество будничных рядовых евангельских зачал могло заменятся столпом дневных евангельских чтений, состав которых в славянских рукописях значительно варьируется. ${ }^{68}$

Использование краткого апракоса Пн-4 без дополнительных чтений (присутствующих в Зг-16) в ежедневной богослужебной жизни афонских монахов является невозможным. Этот памятник мог использоваться лишь в монастырском храме или часовне, или же ските, где богослужения не совершались ежедневно. Популярная даже сегодня на св. горе Афон, особенно в скитах и пустынях, идиоритмическая модель монашеской жизни не предусматривает ежедневных богослужений.

\section{истОЧники}

AP-6 = евангелие апракос краткий, XV в., Румынская Академия Наук, Бухарест, собрание кириллических рукописей, № 6 .

Зг-16 = евангелие апракос краткий, кон. XV - нач. XVI в., Афон, Зографский монастырь, № 16.

КБ-1 = евангелие апракос краткий, кон. XIV - поч. XV в., Российская Национальная Библиотека, Санкт-Петербург, собрание Кирилло-Белозерского Монастыря, № 1.

Пн-4 = апостол апракос краткий и евангелие апракос краткий, ок. 1313 г. (апостол) и кон. XIII - нач. XIV в. (евангелие), Афон, Свято-Пантелеймонов монастырь, № 4 .

Рм-107 = евангелие апракос краткий, I пол. XIV в., Российская государственная библиотека, Москва, собрание Н. П. Румянцева, № 107.

Ц-38 = апостол-евангелие субботне-воскресный апракос, пол. XV в., ЦерковноАрхеологический Музей, София, № 38.

\section{ЛИТЕРАТУРА}

ALAND, K. 1963. Kurzgefasste Liste der Griechischen Handschriften des Neuen Testaments. (Arbeiten zur Neutestamentlichen Textforschung, 1). Berlin: Walter de Grueter $\& \mathrm{Co}$.

ANCHIMIUK, J. 1980. Perykopa ewangeliczna liturgii eucharystycznej w dniu święta Zesłania Ducha Świętego (Ja 7,37-52; 8,12). Rocznik Teologiczny 22/1: 87-103.

68 Рукописи часто содержат разные евангельские чтения на один и тот же день недели (TEMČIN 1999: 175 \{подробнее см. 178-187\}). Состав дневных зачал в Синайском евхологии не находит соответствий в греческой и славянской традициях (TARNANIDIS 1988: 79; DOGRAMADŽIEVA 1994: 63). 
BOBRIK 2014. = БОБРИК, М. А. 2014. В поисках истоков славянского Апостола:

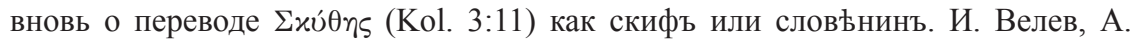
Гиревски, Л. Макаријоска, К. Мокрова (ред.). Кирилометодиевската традиција и македонско-руските духовни и културни врски: зборник на трудови од меѓнародниот научен собир (организиран по повод 1150 години от Моравската мисија и од словенската писменост). Охрид, 3-4 октомври 2013. Скопье: Универзитет св. Кирил и Методиј, 235-247. [BOBRIK, М. А. 2014. V poiskah istokov slavânskogo Apostola: vnov' o perevode Skýthēs (Kol. 3:11) kak skif" ili slověninъ. I. Velev, A. Girevski, L. Makarijoska, K. Mokrova (red.). Kirilometodievskata tradicija i makedonsko-ruskite duhovni i kulturni vrski: zbornik na trudovi od meǵunarodniot naučen sobir (organiziran po povod 1150 godini ot Moravskata misija i od slovenskata pismenost). Ohrid, 3-4 oktomvri 2013. Skop'e: Univerzitet sv. Kiril i Metodij, 235-247.]

BOBRIK 2015. = БОБРИК, М. А. 2015. В поисках истоков славянского Апостола:

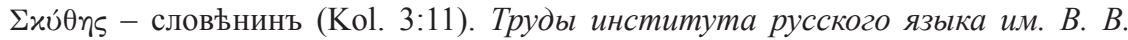
Виноградова 5/5: 69-88. [BOBRIK, M. A. 2015. V poiskah istokov slavânskogo Apostola: Skýthēs - slověnin" (Kol. 3:11). Trudy instituta russkogo âzyka im. V. V. Vinogradova 5/5: 69-88.]

BOBRINSKOY, B. 2004. Życie liturgiczne. Tłum. J. Dembska. (Bogostowije, 4). Warszawa: Bodea.

ČEŽIÂ 2013. = ЧЕЖИЯ, Е. монах (сост.). 2013. Каталог рукописей, печатных книг и архивных материалов Русского Свято-Пантелеимонова Монастыря на Афоне. (Русский Афон XIX-XX веков; № 7). Святая Гора Афон: Русский Свято-Пантелеймонов монастырь на Афоне. [ČEŽIÂ, E. monah (sost.). 2013. Katalog rukopisej, pečatnyh knig i arhivnyh materialov Russkogo Svâto-Panteleimonova Monastyrâ na Afone. (Russkij Afon XIX-XX vekov; № 7). Svâtaâ Gora Afon: Russkij SvâtoPantelejmonov monastyr' na Afone.]

DOGRAMADŽIEVA 1994. = ДОГРАМАДЖИЕВА, Е. 1994. Участие на Евангелието в изграждането на Синайския евхологий. Старобългарска литература 28-29: 62-65. [DOGRAMADŽIEVA, E. 1994. Učastie na Evangelieto v izgraždaneto na Sinajskiâ evhologij. Starob"lgarska literatura 28-29: 62-65.]

GARZANITI, M. 2001. Die altslavische Version der Evangelien: Forschungsgeschichte und zeitgenössische Forschung. (Bausteine zur Slavischen Philologie und Kulturgeschichte. Neue Folge. Reihe A: Slavistische Forschungen. Bd. 33). Köln - Weimar - Wien: Böhlau Verlag.

HRISTOVA; KARADŽOVA; UZUNOVA 2003. = ХРИСТОВА, Б.; Д. КАРАДЖОВА; Е. УЗУНОВА. 2003. Бележки на българските книжовници X-XVIII в. Т. 1 (X-XV в.). София: Народна библиотека Св. Св. Кирил и Методий. [HRISTOVA, B.; D. KARADŽOVA; E. UZUNOVA. 2003. Beležki na b"lgarskite knižovnici X-XVIII v. T. 1 (X-XV v.). Sofiâ: Narodna biblioteka Sv. Sv. Kiril i Metodij.]

IL'INSKIJ 1908. = ИЛЬИНСКІЙ, Г. А. 1908. Рукописи Зографскаго монастыря на Афоне. Известия русского археологического Института в Константинополе XIII: 253-276. [IL'INSKIJ, G. A. 1908. Rukopisi Zografskago monastyrâ na Afone. Izvestiâ russkogo arheologičeskogo Instituta v Konstantinopole XIII: 253-276.] 
IVANOV 1931. = ИВАНОВ, Й. 1931. Български старини из Македония. София: Държавна Печатница (репринт 1970). [IVANOV, J. 1931. B"lgarski starini iz Makedoniâ. Sofiâ: D"ržavna Pečatnica (reprint 1970).]

IOANN 1998. = ИОАНН 1998 = Евангелие от Иоанна в славянской традиции. А. А. Алексеев, А. А. Пичхадзе, М. Б. Бабицкая, И. В. Азарова, Е. Л. Алексеева, Е. Л. Ванеева, А. М. Пентковский, В. А. Ромодановская, Т. В. Ткачева (ред.). СанктПетербург: Российское Библейское Общество (Novum Testamentum Palaeoslovenice I). [IOANN 1998 = Evangelie ot Ioanna v slavânskoj tradicii. A. A. Alekseev, A. A. Pičhadze, M. B. Babickaâ, I. V. Azarova, E. L. Alekseeva, E. L. Vaneeva, A. M. Pentkovskij, V. A. Romodanovskaâ, T. V. Tkačeva (red.). Sankt-Peterburg: Rossijskoe Biblejskoe Obŝestvo (Novum Testamentum Palaeoslovenice I).]

KERN 1999. = КЕРН, К. архимандрит. 1999. Литургика, гимнография и эортология. Москва: Крутицкое Патриаршее Подворье (Богословская Библиотека; кн. 5). [KERN, K. arhimandrit. 1999. Liturgika, gimnografiâ i èortologiâ. Moskva: Krutickoe Patriaršee Podvor'e (Bogoslovskaâ Biblioteka; kn. 5).]

KOVÂZINA 2000. = КОВЯЗИНА, Н. Ф. 2000. Стабильные памяти и евангельские чтения в славянском апракосном Месяцеслове XI-XVI вв. (сентябрь). Slavistica Vilnensis 51-60 (Kalbotyra 49/2): 51-61. [KOVÂZINA, N. F. 2000. Stabil'nye pamâti i evangel'skie čteniâ v slavânskom aprakosnom Mesâceslove XI-XVI vv. (sentâbr'). Slavistica Vilnensis 51-60 (Kalbotyra 49/2): 51-61.]

KODOV; RAJKOV; KOŽUHAROV 1985. = КОДОВ, Х.; Б. РАЙКОВ; С. КОЖУХАРОВ. 1985. Опис на славянските ръкописи в библиотеката на Зографския манастир в Света Гора. София: Издателство »Свят«. [KODOV, H.; B. RAJKOV; S. KOŽUHAROV. 1985. Opis na slavânskite $r^{\prime \prime}$ kopisi v bibliotekata na Zografskiâ manastir v Sveta Gora. Sofiâ: Izdatelstvo »Svât«.]

LAVROV 1916. = ЛАВРОВ, П. А. 1916. Палеографическое обозрение кирилловского письма. (Энциклопедия славянской филологии, 4. 1). Петроградъ: Типография Императорской Академии наук. [LAVROV, P. A. 1916. Paleografičeskoe obozrenie kirillovskogo pis'ma. (Ènciklopediâ slavânskoj filologii, 4. 1). Petrograd": Tipografiâ Imperatorskoj Akademii nauk.]

LOSEVA 2001. = ЛОСЕВА, О. В. 2001. Русские месяцесловы XI-XIV вв. Москва: Памятники исторической мысли. [LOSEVA, O. V. 2001. Russkie mesâceslovy XI-XIV vv. Moskva: Pamâtniki istoričeskoj mysli.]

MAREŠ 1984-1985. = MAРЕШ, В. Ф. 1984-1985. Раннее свидетельство теории о скифском происхождении славян на Руси и на Балканах. Cyrillomethodianum VIII-IX: 37-47. [MAREŠ, V. F. 1984-1985. Rannee svidetel'stvo teorii o skifskom proishoždenii slavân na Rusi i na Balkanah. Cyrillomethodianum VIII-IX: 37-47.]

MAREŠ 1985. = MAРЕШ, В. Ф. 1985. Словен »Скит« во Скопскиот апостол. Семинар за македонски јазик, литература и култура. XI научна дискусија, секиија за литеpamypa (Охрид 13-16 август 1984 г.). Скопје, 119-122. [MAREŠ, V. F. 1985. Sloven »Skit« vo Skopskiot apostol. Seminar za makedonski jazik, literatura i kultura. XI naučna diskusija, sekcija za literatura (Ohrid 13-16 avgust 1984 g.). Skopje, 119-122.]

MATFEJ 2005. = МАТФЕЙ 2005 = Евангелие от Матфея в славянской традиции. А. А. Алексеев, И. В. Азарова, Е. Л. Алексеева, М. Б. Бабицкая , Е. Л. Ванеева, А. А. 
Пичхадзе, В. А. Ромодановская, Т. В. Ткачева (ред.). Санкт-Петербург: Российское Библейское Общество (Novum Testamentum Palaeoslovenice II). [MATFEJ $2005=$ Evangelie ot Matfeâ v slavânskoj tradicii. A. A. Alekseev, I. V. Azarova, E. L. Alekseeva, M. B. Babickaâ, E. L. Vaneeva, A. A. Pičhadze, V. A. Romodanovskaâ, T. V. Tkačeva (red.). Sankt-Peterburg: Rossijskoe Biblejskoe Obŝestvo (Novum Testamentum Palaeoslovenice II).]

MOSZYŃSKI, L. 1985. Zografskie i Mariańskie Tetraewangelia jako księgi liturgiczne, część I: Etap głagolski. Polata Knigopisnaia XIV-XV: 76-99.

MOŠIN 1996. = МОШИН, В. 1966. Палеографски албум на јужнословенското кирилско писмо. Скопје: Кочо Рацин. [MOŠIN, V. 1966. Paleografski album na južnoslovenskoto kirilsko pismo. Skopje: Kočo Racin.]

MUSAKOVA 2009. = МУCАКОВА, Е. 2009. Изборното Евангелие от Центральната Държавна Библиотека в Букурещ и неговите части в сбирките на Рилския и на Зографския Манастир. Кирило-Методиевскии Студии 18: 477-494. [MUSAKOVA, E. 2009. Izbornoto Evangelie ot Central'nata D"ržavna Biblioteka v Bukureŝ i negovite časti v sbirkite na Rilskiâ i na Zografskiâ Manastir. Kirilo-Metodievskii Studii 18: 477-494.]

OSTAPCZUK, J. 2008. Cerkiewnosłowiański przekład Ewangelii Jana okresu Paschalnego w lekcjonarzach nr 4 z klasztoru św. Pantelejmona i nr 2 Serbskiej Akademii Nauk i Sztuki w Belgradzie. Rocznik Teologiczny 50/1-2: 21-53.

OSTAPCZUK, J. 2009. Cerkiewnosłowiański przekład Dobrej Nowiny w rękopisie nr 4 z klasztoru św. Pantelejmona. M. Kuczyńska (red.). Święta Góra Atos w kulturze Europy, Europa w kulturze Atosu. Gniezno: Collegium Europeaum Gnesnense, 70-78.

OSTAPCZUK, J. 2010.a. Cerkiewnosłowiański przekład liturgicznych perykop okresu Paschalnego i święta Pięćdziesiatnicy $w$ rękopiśmiennych ewangeliarzach krótkich. Warszawa: Wydawnictwo Naukowe Chrześcijańskiej Akademii Teologicznej w Warszawie.

OSTAPCZUK, J. 2010.b. Fragmenty cerkiewnosłowiańskich rękopiśmiennych lekcjonarzy w zbiorach Muzeum Narodowego w Pradze (edycja tekstu i klasyfikacja typologiczna). Rocznik Slawistyczny 9: 45-80.

OSTAPCZUK, J. 2013. Sobotnie i niedzielne perykopy liturgiczne z Ewangelii Mateusza w cerkiewnosłowiańskich lekcjonarzach krótkich. Warszawa: Wydawnictwo Naukowe Chrześcijańskiej Akademii Teologicznej w Warszawie.

OSTAPCZUK, J. 2016. Czy cerkiewnosłowiańskie ewangeliarze krótkie były kopiowane z pełnych? A. Alberti, M. C. Ferro, F. Romoli (eds.). Mosty mostite. Studi in onore di Marcello Garzaniti. (Biblioteca di Studia Slavistici 34). Firenze: Firenze University Press, 119-133.

OSTAPČUK 2015. = ОСТАПЧУК, Е. 2015. Новые фрагменты рукописных кириллических Евангелий из собраний Афонских монастырей. С. Шумило (ред.). Афонское Наследие. Научный Альманах 1-2 (Материаль международной научной конференции »Русь и Афон: тысячелетие духовно-культурных связей«, Чернигов, 28-29 ноября 2014 г.) Киев - Чернигов: Международный институт афонского наследия в Украине, 304-316. [OSTAPČUK, Е. 2015. Novye fragmenty rukopisnyh kirilličeskih Evangelij iz sobranij Afonskih monastyrej. S. Šumilo (red.). Afonskoe Na- 
sledie. Naučnyj Al'manah 1-2 (Materialy meždunarodnoj naučnoj konferencii »Rus' $i$ Afon: tysâčeletie duhovno-kul'turnyh svâzej«, Černigov, 28-29 noâbrâ 2014 g.) Kiev - Černigov: Meždunarodnyj institut afonskogo naslediâ v Ukraine, 304-316.]

PILAT 2013. = ПИЛАТ, Ш. 2013. Орфографические, фонетические и морфологические особенности Скопльского Апостола, церковнославянского памятника 1313 года. М. Бобрик (ред.). Славянский Апостол: история текста и языка. (Studies on Language and Culture in Central and Eastern Europe, 21). Berlin - Washington: Kubon\&Sagner, 165-181. [PILAT, Š. 2013. Orfografičeskie, fonetičeskie i morfologičeskie osobennosti Skopl'skogo Apostola, cerkovnoslavânskogo pamâtnika 1313 goda. M. Bobrik (red.). Slavânskij Apostol: istoriâ teksta i âzyka. (Studies on Language and Culture in Central and Eastern Europe, 21). Berlin - Washington: Kubon\&Sagner, 165-181.]

PILÁT, Š. 2014. Jazyková analýza Skopského apoštolu. Disertačni práce. Vedoucí práct - PhDr. Zdenka Ribarova. Univerzita Karlova v Praze. Filozofická fakulta. Katedra jihoslovanských a balkanistických studií. Filologie - Slovanské filologie.

RAJKOV; KOŽUHAROV; MIKLAS; KODOV 1994. = РАЙКОВ, Б.; С. КОЖУХАРОВ; Х. МИКЛАС; Х. КОДОВ. 1994. Каталог на славянските ръкописи в Библиотеката на Зографския Манастир в Света Гора. София: CIBAL. [RAJKOV, B.; S. KOŽUHAROV; H. MIKLAS; H. KODOV. 1994. Katalog na slavânskite r"kopisi v Bibliotekata na Zografskiâ Manastir v Sveta Gora. Sofiâ: CIBAL.]

Svodnij katalog XIVv. = Сводный каталог XIV в. = Сводный каталог славяно-русских рукописных книг, хранящихся в России, странах СНГ и Балтии, ХІV век, выпуск 1 (Апокалипсис - Летопись Лаврентьевская). О. А. Князевская, Н. А. Кобяк, А. Л. Лифшиц, Н. Б. Тихомиров, А. А. Турилов, Н. Б. Шеламанова (ред.). Москва: Индрик. [Svodnyj katalog XIV v. = Svodnyj katalog slavâno-russkih rukopisnyh knig, hranâsihsâ v Rossii, stranah SNG i Baltii, XIV vek, vypusk 1 (Apokalipsis - Letopis Lavrent'evskaâ). O. A. Knâzevskaâ, N. A. Kobâk, A. L. Lifšic, N. B. Tihomirov, A. A. Turilov, N. B. Šelamanova (red.). Moskva: Indrik.]

STANČEV; DŽUROVA 1981. = CTAНЧEB, К.; А. ДЖУРОВА. 1981. Археографски бележки от Националната Библиотека в Атина. Старобългарска Литература 9: 33-75. [STANČEV, K.; A. DŽUROVA. 1981. Arheografski beležki ot Nacionalnata Biblioteka v Atina. Starob"lgarska Literatura 9: 33-75.]

STOJ̌ANOVIĆ 1902. = СТОЈАНОВИЋ, Љ. 1902. Стари српски записи и натписи. Књ. 1. Београд: Српска Краљевска Академија (репринт 1982). [STOJ̌ANOVIĆ, L. 1902. Stari srpski zapisi i natpisi. Kn̂. 1. Beograd: Srpska Kralevska Akademiǰa (reprint 1982).]

ŠMEMAN 1961. = ШMEMAH, А. 1961. Введение в литургическое богословие. Париж: YMCA-Press. [ŠMEMAN, A. 1961. Vvedenie v liturgičeskoe bogoslovie. Pariž: YMCA-Press.]

TARNANIDIS, I. C. 1988. The Slavonic Manuscripts Discovered in 1975 at St Catherine's Monastery on Mount Sinai. Thessaloniki: St. Catherine's Monastery at Mount Sinai and Hellenic Association for Slavic Studies Thessaloniki.

TACHIAOS, A. E. 1981. The Slavonic manuscripts of Saint Panteleimon monastery (Rossikon) on Mount Athos. Thessaloniki - Los Angeles: Hellenic Association for Slavic Studies Thessaloniki / Center for Russian and East European Studies UCLA. 
TEMČIN 1998. = ТЕМЧИН, С. Ю. 1998. Текстологическая семья Мстиславова евангелия: новые данные о группировке древнерусских списков полного апракоса. Slavistica Vilnensis (Kalbotyra) 47/2: 133-233. [TEMČIN, S. Û. 1998. Tekstologičeskaâ sem'â Mstislavova evangeliâ: novye dannye o gruppirovke drevnerusskih spiskov polnogo aprakosa. Slavistica Vilnensis (Kalbotyra) 47/2: 133-233.]

TEMČIN 1999. = ТЕМЧИН, С. Ю. 1999. Состав дневных евангельских чтений в церковнославянских литургических рукописях. Slavistica Vilnensis (Kalbotyra) 48/2: 173-197. [TEMČIN, S. Û. 1999. Sostav dnevnyh evangel'skih čtenij v cerkovnoslavânskih liturgičeskih rukopisâh. Slavistica Vilnensis (Kalbotyra) 48/2: 173-197.]

TEMČIN 2001. = ТЕМЧИН, С. Ю. 2001. Столпный апракос - еще один неизвестный структурный тип славянского Евангелия (по рукописям XIII-XVI веков). Г. Баранкова (ред.). Библия в духовной жизни, истории и культуре России и православного славянского мира: К 500-летию Геннадиевской Библии. Сборник материалов международной конференции (Москва, 21-26 сентября 1999 г.). Москва: Библейско-богословский Институт св. апостола Андрея, 127-159. [TEMČIN, S. Û. 2001. Stolpnyj aprakos - eŝe odin neizvestnyj strukturnyj tip slavânskogo Evangeliâ (po rukopisâm XIII-XVI vekov). G. Barankova (red.). Bibliâ v duhovnoj žizni, istorii i kul'ture Rossii i pravoslavnogo slavânskogo mira: K 500-letiû Gennadievskoj Biblii. Sbornik materialov meždunarodnoj konferencii (Moskva, 21-26 sentâbrâ 1999 g.). Moskva: Biblejsko-bogoslovskij Institut sv. apostola Andreâ, 127-159.]

TEMČIN 2010.a. = ТЕМЧИН, С. Ю. 2010.а. Структурные особенности кодекса Тп-14, содержащего Саввину Книгу. Исследования по кирилло-мефодиевистике и палеославистике. (Krakowsko-Wileńskie Studia Slawistyczne, t. 5) Kraków: Scriptum, 71-98. [TEMČIN, S. Û. 2010.a. Strukturnye osobennosti kodeksa Tp-14, soderžaŝego Savvinu Knigu. Issledovaniâ po kirillo-mefodievistike i paleoslavistike. (KrakowskoWileńskie Studia Slawistyczne, t. 5) Kraków: Scriptum, 71-98.]

TEMC̆IN 2010.b. = ТЕМЧИН, C. Ю. 2010.b. Сербский столпный апракос Равулы (ок. 1353 г.): происхождение, особенности языка, структура. Исследования по кирилло-мефодиевистике и палеославистике. (Krakowsko-Wileńskie Studia Slawistyczne, t. 5). Kraków: Scriptum, 147-193. [TEMČIN, S. Û. 2010.b. Serbskij stolpnyj aprakos Ravuly (ok. 1353 g.): proishoždenie, osobennosti âzyka, struktura. Issledovaniâ po kirillo-mefodievistike i paleoslavistike. (Krakowsko-Wileńskie Studia Slawistyczne, t. 5). Kraków: Scriptum, 147-193.]

TURILOV 2006. = ТУРИЛОВ, А. А. 2006. Сербские отрывки XIII-XVI вв. библиотеки Русского Пантелеймонова монастыря на Афоне. Ч. 1 (Рукописи 13-14 вв). Apхеграфски прилози 28: 56-104. [TURILOV, A. A. 2006. Serbskie otryvki XIII-XVI vv. biblioteki Russkogo Pantelejmonova monastyrâ na Afone. Č. 1 (Rukopisi 13-14 vv). Arhegrafski prilozi 28: 56-104.]

TURILOV 2010. = ТУРИЛОВ, А. А. 2010. К изучению южнославянской рукописной традиции »Прогласа Константина Философа«. М. Йовчева (ред.). Пение мало Георгию: Сборник в чест на 65-годишнината на проф. дфн. Георги Попов. София: Издателски център Боян Пенев, 346-357. [TURILOV, A. A. 2010. K izučeniû ûžnoslavânskoj rukopisnoj tradicii »Proglasa Konstantina Filosofa«. M. Jovčeva (red.). Penie malo Georgiû: Sbornik v čest na 65-godišninata na prof. dfn. Georgi Popov. Sofiâ: Izdatelski cent"r Boân Penev, 346-357.] 
TURILOV 2012. = ТУРИЛОВ, А. А. 2012. О датировке и писце среднеболгарского Евангелия апракос при Скопском Апостоле 1313 г. Г. К. Венедиктов, Е. Мирчева (ред.). Язык Библии: Лингво-текстологические исследования. Москва - Санкт-Петербург: Нестор-История, 120-126. [TURILOV, А. А. 2012. O datirovke i pisce srednebolgarskogo Evangeliâ aprakos pri Skopskom Apostole 1313 g. G. K. Venediktov, E. Mirčeva (red.). Azyk Biblii: Lingvo-tekstologičeskie issledovaniâ. Moskva - Sankt-Peterburg: Nestor-Istoriâ, 120-126.]

TURILOV; MOŠKOVA 1999. = ТУРИЛОВ, А. А.; Л. В. МОШКОВА. 1999. Славянские рукописи Афонских обителей. Фессалоники: Ss Cyril and Methodius Center for Cultural Studies. [TURILOV, A. A.; L. V. MOŠKOVA. 1999. Slavânskie rukopisi Afonskih obitelej. Fessaloniki: Ss Cyril and Methodius Center for Cultural Studies.]

VRANA, J. 1960. O tipovima, redakcijama i međusobnom odnosu staroslovjenskih evanđelija (Četveroevanđelja). Slavia 29/X: 552-571.

ŽUKOVSKAÂ 1968. = ЖУКОВСКАЯ, Л. П. 1968. Типология рукописей древнерусского полного апракоса XI-XIV вв. в связи с лингвистическим изучением их. В. В. Виноградов (ред.). Памятники древнерусской письменности: язык и текстология. Москва: Наука, 252-260. [ŽUKOVSKAÂ, L. P. 1968. Tipologiâ rukopisej drevnerusskogo polnogo aprakosa XI-XIV vv. v svâzi s lingvističeskim izučeniem ih. V. V. Vinogradov (red.). Pamâtniki drevnerusskoj pis'mennosti: âzyk i tekstologiâ. Moskva: Nauka, 252-260.]

ŽUKOVSKAÂ 1971. = ЖУКОВСКАЯ, Л. П. 1971. Рукопись № 9 из собрания Григоровича. Советское Славяноведение 3: 86-87. [ŽUKOVSKAÂ, L. P. 1971. Rukopis' № 9 iz sobraniâ Grigoroviča. Sovetskoe Slavânovedenie 3: 86-87.]

ŽUKOVSKAÂ 1976. = ЖУКОВСКАЯ, Л. П. 1976. Текстология и язык древнейших славянских памятников. Москва: Наука. [ŽUKOVSKAÂ, L. P. 1976. Tekstologiâ $i$ âzyk drevnejših slavânskih pamâtnikov. Moskva: Nauka.]

\section{Sažetak \\ Jerzy Ostapczuk \\ LITURGIJSKE ZNAČAJKE U STRUKTURI RUKOPISNIH EVANĐELJA IZ DVAJU SVETOGORSKIH SAMOSTANA NAMIJENJENIH PAROHIJSKOM BOGOSLUŽJU}

Članak sadrži opće informacije o crkvenoslavenskim rukopisnim evanđeljima koja se čuvaju na Svetoj Gori (Atosu), kao i opis liturgijskih značajki prvih dvaju odjeljaka sinaksarnoga dijela bogoslužbenoga ciklusa (uskrsnoga i nakon blagdana Pedesetnice) u dvama kraćim aprakosima. Jedan rukopis čuva se u svetogorskom samostanu sv. Pantelejmona (br. 4), a drugi u Zografskom (br. 16). U članku se raspravlja o mogućnosti služenja ovim dvama kraćim aprakosima, namijenjenima parohijskom bogoslužju, tijekom svakodnevnoga bogoslužja u manastirima.

Ključne riječi: liturgijske značajke, kraći aprakos, Sveta Gora (Atos) 


\section{Summary}

Jerzy Ostapczuk

\section{LITURGICAL FEATURES IN THE STRUCTURE OF THE GOSPEL MANUSCRIPTS OF THE CATHEDRAL AND PARISH WORSHIP FROM MONASTIC REPOSITORIES ON MOUNT ATHOS}

The present article contains general information about Gospel manuscripts preserved at the monasteries on the Holy Mount Atos and describes liturgical features of the two first periods of movable calendar (Easter and after Holy Pentecost) in two short Gospel lectionaries. The first manuscript is preserved at St Panteleimon Monastery (No 4) and the second at Zograf Monastery (No 16) on Mount Athos. The article also discusses the possibility of using these two short Gospel lectionaries, intended for use in cathedral churches and parishes, in the monastic daily worship.

Keywords: liturgical features, short lectionary, Mount Athos 